\title{
Considerations on the Mechanism of Establishment of Parametric Oscillation Voltage in a Single-phase Input Three-phase Parametric Motor
}

\author{
Hiroshi Kawamorita, Masaaki Yoshida, Mitsuo Natsusaka, and Yoshinori Sakamoto \\ Hachinohe Institute of Technology, 88-1, Ohbiraki, Myo, Hachinohe 031-8501
}

\begin{abstract}
The practical use of a single-phase motor having a three-phase rotating field is very useful for energy conservation. We have been studying a single-phase input three-phase parametric motor and have succeeded in generating a three-phase rotating magnetic field in the stator. However, the mechanism for generating three-phase voltage has not yet been clarified. This paper discusses the factors that cause three-phase voltage based on the excitation voltage dependence of state of parametric oscillation and the change of the frequency of parametric oscillation voltage.
\end{abstract}

Key words: parametric motor, parametric oscillation, three-phase induction motor, three-phase rotating field, rotational direction, resonance side frequency

\section{単相励磁入カ三相パラメトリックモータの パラメトリック発振電圧確立機構に関する考察}

\author{
川守田 大志・吉田 雅昭・夏坂 光男・坂本 禎智 \\ 八戸工業大学，青森県八戸市大字妙字大開 88-1（†031-8501）
}

\section{1. はじめに}

近年，エアコンやクーラーなどの家電製品，工業用機械等，モ 一タを使用している多種多様な製品の利便性の向上に伴い，それ らの需要が増加している. モータの需要が増え続けることに比 例してその消費電力も増えてきており, 電力需要の概要を調 ベてみると, 消費電力量は全発電電力量の約半分以上を占 めている. そのため, モータを高出力-高効率化させることによ る消費電力を抑える技術の確立が急がれている.

誘導モー夕は構造が簡単, 長寿命, 安価, 保守が容易といった 特徵を有し，未だに多くの分野で使用されている. 一般の市販 誘導モータとして単相誘導モータと三相誘導モータが挙げら れるが, 三相誘導モータの方が空隙部分における起磁力の空 間高調波成分が少ないことから, 同一出力時において効率が 良いことが知られている. 従って, 三相誘導モ一夕を一般家庭 やオフィス等で使用することが出来れば, 省エネルギー対策と しても有効である. しかし, 三相誘導モー夕を一般家庭等で使 用するとなると, 単相配線を三相配線に敷設しなおさなければ ならない, また, 単相配線を利用するにしても単相-三相変換イ ンバータなどの変換機が必要であるといら問題が生じ, コスト 面や手間が負担となってしまう.このような背景から, 筆者等は, 単相電源を用いて三相誘導モータと同等の回転磁界を生成 できるモータの実現・実用化は極めて有効であると考えてい る.

本研究に用いられる単相励磁入力・三相パラメトリックモータ 1) 4)は，パラメトリック発振回路を 2 系統に設けることで三相回 転磁界の実現に成功している5)。これまでの研究では, 固定子 材質に磁化容易軸を設けた磁気異方性材料を用いてモータ の試作を行い, 固定子内磁束密度分布を不平衡にすることで
発振の安定化を目指した結果, 振幅や位相差において三相 類似波形を得ることができた ${ }^{6) ~ 8) . ~}$

本モー夕を使用するためには，モータの動作点を定めたとき， スイッチの投入後に動作しなければならない. しかし本モータ の場合は, 設計法が確立されておらず, まだ、動作点を定める ことができない. その理由は, パラメトリックモータの場合, 励磁 電圧 $\mathrm{E}_{1}$, 励磁周波数 $\mathrm{f}$, 回転数 $\mathrm{N}$ の増減によってパラメトリック 発振現象に履歴特性が存在し, 現時点では決まった動作点を 定めることができないからである. そこで本論文では, 出力, 効 率の改善に関することには言及せず,三相パラメトリックモータ として動作する点に移行する発振電圧確立機構を明確にする ために, 励磁電圧 $\mathrm{E}_{1}$ の増減による共振側電圧確立状況, そし て, 励磁周波数 $\mathrm{f}$ に対する共振側周波数の変化に着目をして 検討を行った. その結果, 三相電圧確立の要因として, 2 系統 ある共振側の電圧確立状況と回転方向の関係, また, 共振側 電圧の倍周波発振が関係していることが明確となった. 本論 文では,これらの検討結果について報告する.

\section{2. 基本構成}

Fig. 1 に本モータの基本構成を示す. Table 1 に実験に 用いたモータの固定子および回転子寸法を示す. 固定子の 磁極を $60^{\circ}$ ごとに配置し, パラメトリック発振回路 2 系統 を空間的に $120^{\circ}$ おび $240^{\circ}$ となるように設計を施すこと で，回転子部に生成される磁界方向を定めている，交流電 源 $\mathrm{E}_{1}$ を接続している脚部を励磁側磁路, 同調用コンデン サを励磁側磁路に対し $120^{\circ}$ 方向に接続している脚部を共 振側 $\mathrm{A}$, 同様に $240^{\circ}$ 方向に接続している脚部を共振側 $\mathrm{B}$, 回転子付近の環状部を内側共通磁路, 外側の環状部を外側 
共通磁路と称している. 内側共通磁路はパラメトリック発 振に必要な磁気飽和を生じ易くするため, 外側共通磁路よ りも細く設計している.

今回, 検討に用いられるモータとして, 内側共通磁路幅 $4 \mathrm{~mm}$, 外側共通磁路幅 $10 \mathrm{~mm}$ とした 4 つのモータ, \#1L60 ${ }^{\circ}$, \#1L(-60) ${ }^{\circ}, \# 2 / 3 \mathrm{~L} 60^{\circ} \mathrm{Cross}, \# 1 / 2 \mathrm{~L} 60^{\circ} \mathrm{Cross}$ を 用いた．各部の寸法は Table 1 に示した通りであり，それ ぞれのモータの寸法には違いがないが，\#1L60と \#1L(-60)は励磁側磁極と共振側磁極が同じ断面積になる ように積層している. また, \#2/3L $60^{\circ}$ Cross は共振側磁極 の断面積が\#1L の $2 / 3$ になるように, 同様に \#1/2L60Cross は 1/2 になるように積層をしている. Fig. 2 に固定子形状の違いを示す．磁化容易軸方向は，\#1L60 が共振側 A の方向である $60^{\circ}$ に, \#1L(-60) が共振側 B の 方向である(-60)に設けられている. また, 共振側磁極が 分割された\#2/3L $60^{\circ}$ Cross 及び\# $1 / 2 \mathrm{~L} 60^{\circ} \mathrm{Cross}$ は, それぞ れ分割された共振側磁極の方向である $60^{\circ},(-60)^{\circ}$ に磁化 容易軸を揃え，交差するような形で作られている. Fig. 3 に各モータ固定子の磁化容易軸方向を示す.これらのモー タを用いて検討を行う意義は二つある. 固定子に磁気異方 性を設けることでパラメトリック発振の確立に重要なイ ンダクタンス L の変化による影響を知ることができるこ と，そして，共振側磁極の断面積に違いを設けることによ り, お互いの共振側磁極が果たす発振確立への役割を明確 にすることができることである.これらのモータで三相電 圧確立の共通要因を見出すことができれば, それらの要因 は三相電圧確立にとって極めて重要であることを示して いる. 比較検討時のコンデンサ容量は, 巻線の許容電流の 関係上 $20 \mu \mathrm{F}$ を上限とし, 基本的に $\mathrm{C}_{\mathrm{a}}=10 \mu \mathrm{F}, \mathrm{Cb}_{\mathrm{b}}=20 \mu \mathrm{F}$ を使用している. 各モータの固定子には，共に厚さ 0.35 $\mathrm{mm}$ の方向性ケイ素鋼板を用い 55 枚あるいは 56 枚積層 した．巻き線数は $\mathrm{N}_{1}=\mathrm{N}_{2 \mathrm{a}}=\mathrm{N}_{2 \mathrm{~b}}=1000$ turns である.



Fig. 1 Outline of structure.

Table 1 Stator and rotor dimensions. (Unit : $\mathrm{mm}$ )

\begin{tabular}{|c|c|c|c|c|c|c|c|c|c|}
\hline \multirow{2}{*}{ Motor } & \multicolumn{6}{|c|}{ Stator } & \multicolumn{2}{|c|}{ Rotor } & \multirow{2}{*}{ Direction } \\
\hline & $\mathrm{a}$ & \begin{tabular}{c|}
$\mathrm{c}$ \\
\end{tabular} & $\mathrm{d}$ & $\mathrm{g}$ & $\mathrm{t}$ & \begin{tabular}{|l|} 
Ds \\
\end{tabular} & l & Dr & \\
\hline$\# 1 \mathrm{~L} 60^{\circ}$ & 15 & 10 & 4 & 0.25 & 20.0 & 100 & 19 & 41.5 & $60^{\circ}$ \\
\hline$\# 1 \mathrm{~L}(-60)^{\circ}$ & 15 & 10 & 4 & 0.25 & 20.0 & 100 & 19 & 41.5 & $(-60)^{\circ}$ \\
\hline \#2/3L60 ${ }^{\circ}$ Cross & 15 & 10 & 4 & 0.25 & 20.0 & 100 & 19 & 41.5 & $60^{\circ},(-60)^{\circ}$ \\
\hline \#1/2L60 ${ }^{\circ}$ Cross & 15 & 10 & 4 & 0.25 & 20.0 & 100 & 19 & 41.5 & $60^{\circ},(-60)^{\circ}$ \\
\hline
\end{tabular}

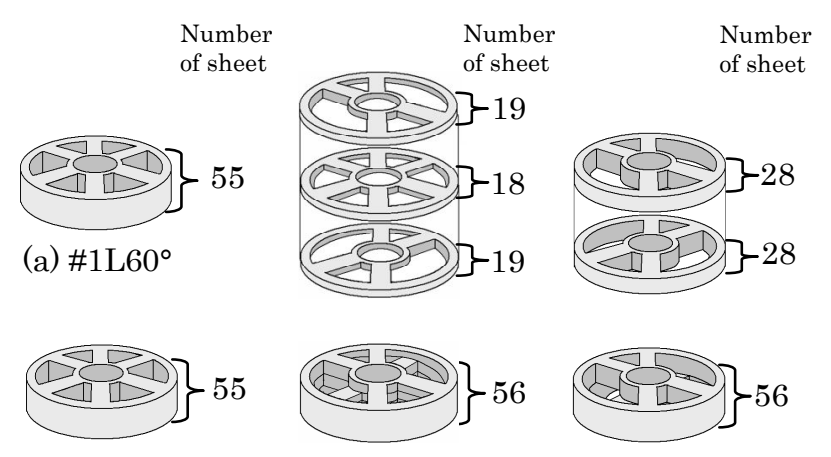

(b) \#1L(-60) ${ }^{\circ}$

(c) \#2/3L $60^{\circ}$ Cross

(d) $\# 1 / 2 \mathrm{~L} 60^{\circ} \mathrm{Cross}$

Fig. 2 Difference of stator shape of each motor.
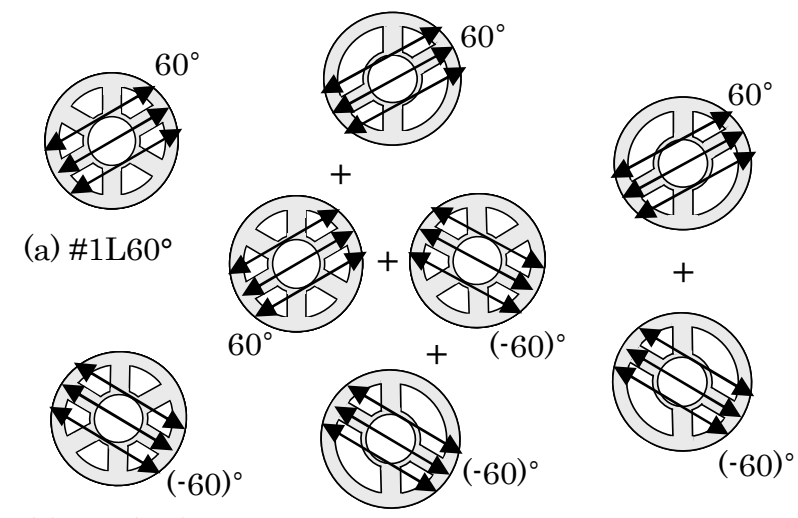

(b) \#1L(-60) ${ }^{\circ}$

(c) \#2/3L60 ${ }^{\circ}$ Cross

(d) \#1/2L $60^{\circ}$ Cross

\section{3. 各モ一タの実験結果}

\section{1 回転方向と発振の確立状況についての考察 (CCW 始動時)}

Fig. 4 に無負荷 Counter clockwise(以下 CCW)始動時の 入出力電圧特性を示す. 測定は, 励磁電圧を徐々に増加し, 最大電流值まで上昇させた後, 励磁電圧を降下させて行っ た. また, 励磁電圧を増加したとき, あるポイントから発振が生 じる.このときに CCW 方向に回転が始まるため, CCW 始動時 と称している. $\mathrm{C}_{\mathrm{a}}=10 \mu \mathrm{F}, \mathrm{C}_{\mathrm{b}}=20 \mu \mathrm{F}$ 動作時の回転方向を Fig. 5 に示す.

Fig. 4 より, 励磁電圧を増加すると, どのモータとも $40 \mathrm{~V}$ 付 近で発振が生じ, Fig. 5(a)に示すとおり CCW 方向に回転が 始まる. しかし，このときはまだ, コンデンサ容量の大きい側で ある共振側 B の発振条件は整っていないと考えられる.このこ とは, 三相パラメトリックモータを単相駆動させることにより考察 が出来る. Fig. 6 に単相駆動時の入出力電圧特性を示す. 例 として, \#1L60と\#1/2L60Cross の特性を用いる. また, 同図 (a)は，共振側 $\mathrm{A}$ にのみコンデンサを設け，共振側 B を開 放して動作をさせた場合であり，同図(b)は共振側 B にの みコンデンサを設け, 共振側 $\mathrm{A}$ を開放して動作をさせた場 合の入出力電圧特性を表している. (A)のモータ\# $1 \mathrm{~L} 60^{\circ}$ に ついて見ると, コンデンサ容量の小さい共振側 A の発振条件 は 40 50 V 付近で整っているのに対して, コンデンサ容量の 
大きい共振側 $\mathrm{B}$ の発振条件は，40 V 付近ではまだ整って いないことがわかる。これは，(B)のモータ\# $1 / 2 \mathrm{~L} 60^{\circ} \mathrm{Cross}$ でも，共振側磁極がお互い独立しているにもかかわらず， 同じことが言える.これにより，共振側 B の発振条件はま だ整っていないと考えられる.また, 単相駆動時の回転方 向を Fig. 7 に示す. 単相駆動時では，共振側 A にのみコ ンデンサを設け動作をさせた場合 $\mathrm{CCW}$ 方向に回転をする. 逆に, 共振側 B のみの場合では Clockwise(以下 $\mathrm{CW}$ )方向 に回転をするという結果が各モータで得られた。このこと から, Fig. 5(a)に示すように CCW 方向に回転が始まるのは, 先に発振条件の整った共振側 $\mathrm{A}$ が生成する回転磁界によるも のだと考えられる.

Fig. 4 より, $\mathrm{E}_{2 \mathrm{a}}$ の発振確立後に続けて励磁電圧を増加し続 けると, 各モータとも 80 90 V 付近から同相となり, 回転数が 減少する.このとき, 先に発振条件が整っていた共振側 A の 生成する回転磁界と, 励磁側および共振側 A の電圧の影響 により, 発振条件が整い始める共振側 B の生成する回転磁界 の, お互いの回転磁界が Fig. 5(b)に示すように相殺するよ うな形で影響しあっていると考えられる。このことにより， 同相領域での回転数の減少が見られたと思われる. その後, 再び励磁電圧を増加すると, $100 \sim 110 \mathrm{~V}$ 付近で共振側 B の発振条件が整うことで, 共振側 B が生成する回転磁界が 勝り，自発的に Fig. 5(c)に示すように, CW 方向に回転し 始める. 以降は，このまま $\mathrm{CW}$ 方向に回転し続け，この後 に励磁電圧を降下させていく過程において, \#2/3L $60^{\circ} \mathrm{Cross}$ 以外のモータでは $60 \sim 80 \mathrm{~V}$ 付近で三相電圧が出力された.

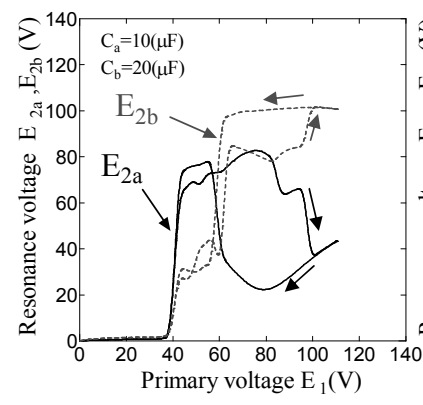

(a) \#1L60

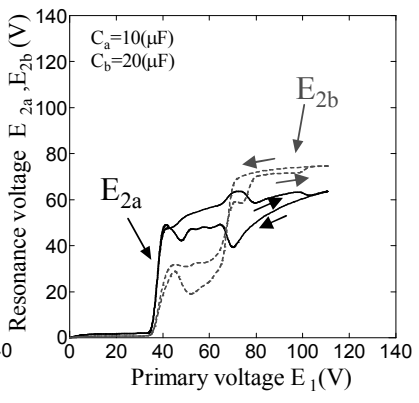

(c) \#2/3L60 ${ }^{\circ}$ Cross

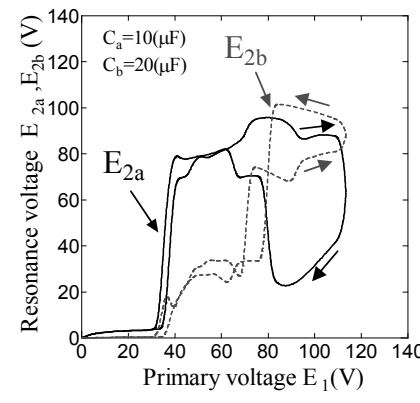

(b) $\# 1 \mathrm{~L}(-60)^{\circ}$

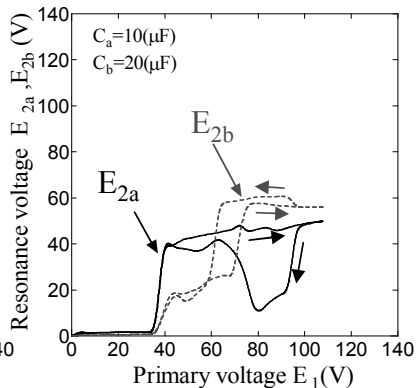

(d) \#1/2L60 ${ }^{\circ}$ Cross
Fig. 4 Primary voltage vs. resonance voltages at no-load. (Counter clockwise)

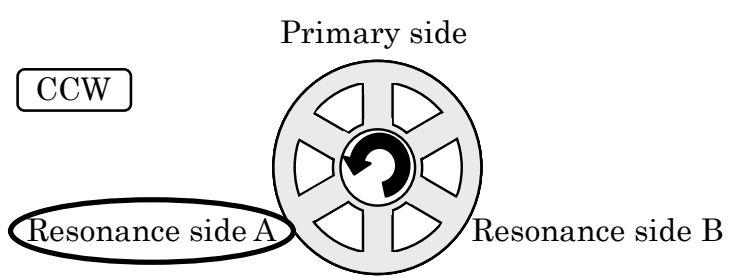

(a) After oscillation

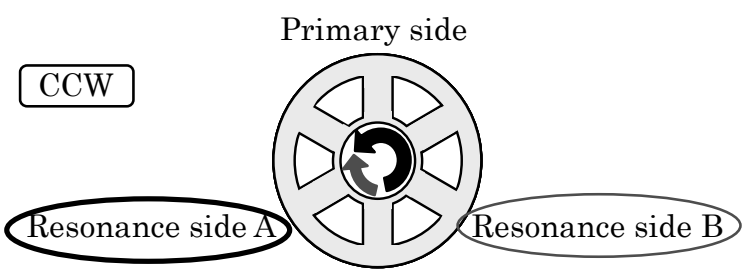

(b) In-phase

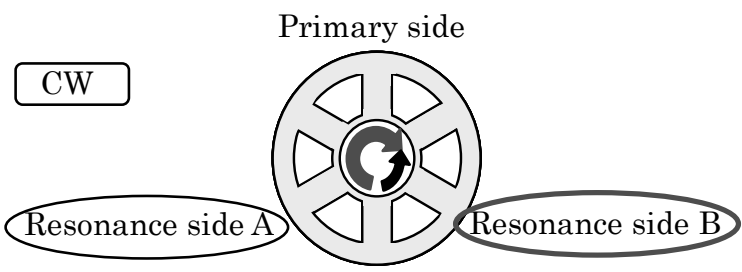

(c) Before three-phase

Fig. 5 Rotational direction at $\mathrm{C}_{\mathrm{a}}=10 \mu \mathrm{F}, \mathrm{C}_{\mathrm{b}}=20 \mu \mathrm{F}$.

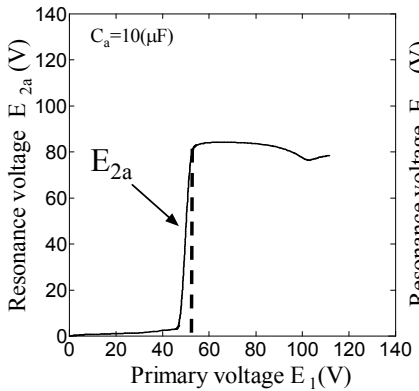

(a) Resonance side A

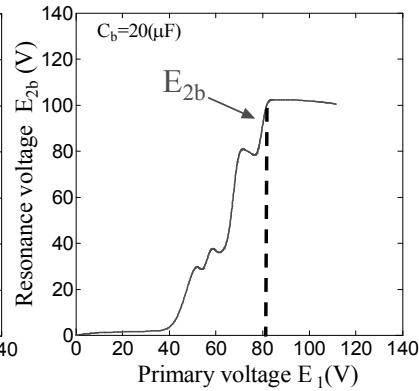

(b) Resonance side B
(A) \#1L60



(a) Resonance side $\mathrm{A}$

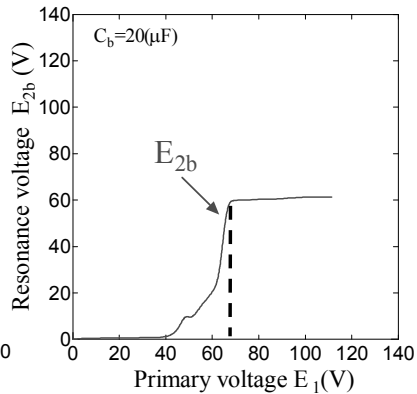

(b) Resonance side B
(B) \#1/2L $60^{\circ} \mathrm{Cross}$

Fig. 6 Primary voltage vs. resonance voltages. 


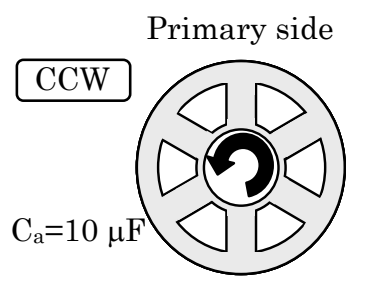

(a) Resonance side A

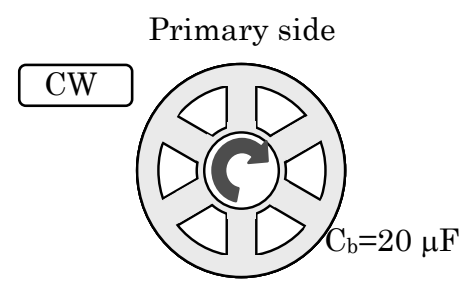

(b) Resonance side B
Fig. 7 Rotational direction in case driven by single-phase voltage.

\section{2 回転方向と発振の確立状況についての考察 (CW 始動時)}

前項の考察より, 三相電圧が出力された回転方向は $\mathrm{CW}$ 方向であったことから, 次に, 強制的に CW 方向から始動 をさせた場合にどのような結果が得られるのか実験を行 った. 前項より, 励磁電圧 $40 \mathrm{~V}$ 付近で発振が生じた際の回 転方向は CCW 方向であるが，そこに手回しで回転方向と は逆方向に回転力を加えると CW 方向のまま動作をし始 める. Fig. 8 に無負荷 CW 始動時の入出力電圧特性を示す. 同図より, 各モータとも $40 \mathrm{~V}$ 付近で発振が生じ, $\mathrm{CW}$ 方向に動 作をさせたあと, 再び励磁電圧を増加し続ける過程において, \#1L(-60)以外のモータでは 60 70 V 付近で共振側 B の発 振条件が整い, このときに三相電圧が出力された. この後, 励磁電圧を増加すると\#1L(-60)。でも $100 \mathrm{~V}$ 付近で共振側 $\mathrm{B}$ の発振条件が整い, このまま回転方向は変わらずに最大 電流值に達し, 励磁電圧を降下させていく過程において, \#2/3L $60^{\circ} \mathrm{Cross}$ 以外のモータでは 60 80 V 付近で三相電圧 が出力された.

Fig. 9 に出力された各モータの三相類似波形を示す.これ らの考察から, 三相電圧確立のための回転方向としては, 同 図より, 励磁側波形に対して共振側 $\mathrm{A}$ の波形が進み位相, そ して共振側 B の波形が遅れ位相になることで三相類似波形が 出力されたことから, CW 方向に回転をすることが望ましいとい える.

\section{3 倍周波発振と三相電圧確立状況についての考察}

前項より, 三相電圧確立のための回転方向は $\mathrm{CW}$ 方向で あると考察を行ったが, その回転方向という要因のみでは, $\mathrm{CW}$ 方向に回転したあとの励磁電圧降下時の \#2/3L60 ${ }^{\circ}$ Cross や CW 始動時での励磁電圧増加過程の \#1L(-60)なな゙，条件を満たしていても三相電圧が出力さ れなかったモータがある. そこで，回転方向という要因の みではなく，そこに共振側電圧の倍周波発振という要因も 加えて考察を行った.

まず, $\mathrm{CCW}$ 始動時の場合, 励磁電圧を増加し続け, コ ンデンサ容量の大きい側の発振条件が整った際に CW 方 向に回転をし始めるが，このとき，コンデンサ容量の小さ い側の共振側電圧の周波数が\# $1 / 2 \mathrm{~L} 60^{\circ} \mathrm{Cross}$ では $100 \mathrm{~Hz}$, そのほかのモータでは $150 \mathrm{~Hz}$ に増加をした. Fig. 10 に各

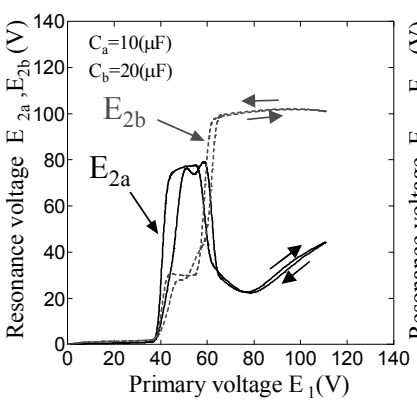

(a) $\# 1 \mathrm{~L} 60^{\circ}$

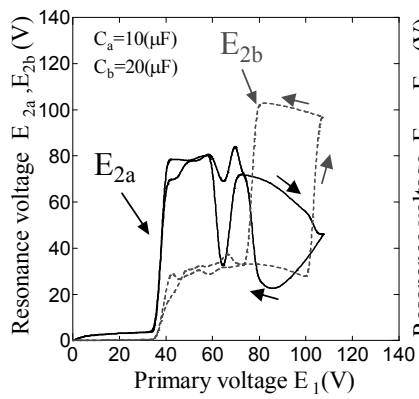

(b) \#1L(-60) ${ }^{\circ}$

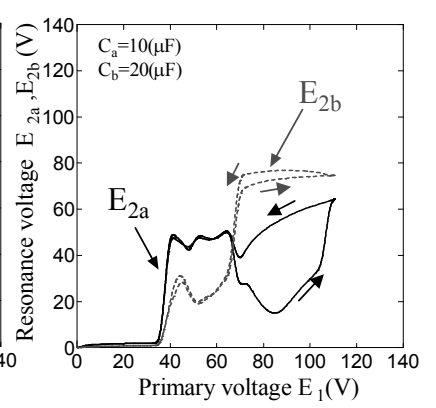

(c) $\# 2 / 3 \mathrm{~L} 60^{\circ}$ Cross

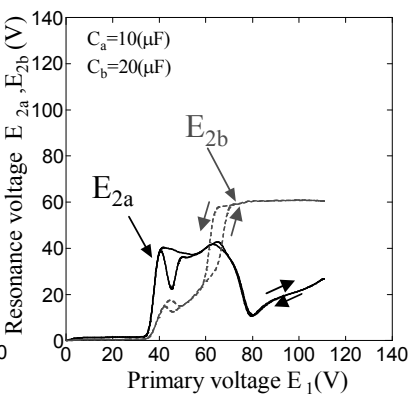

(d) \#1/2L $60^{\circ}$ Cross

Fig. 8 Primary voltage vs. resonance voltages at no-load. (clockwise)

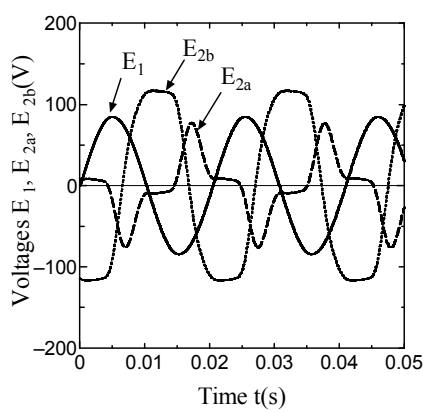

(a) $\# 1 \mathrm{~L} 60^{\circ}$

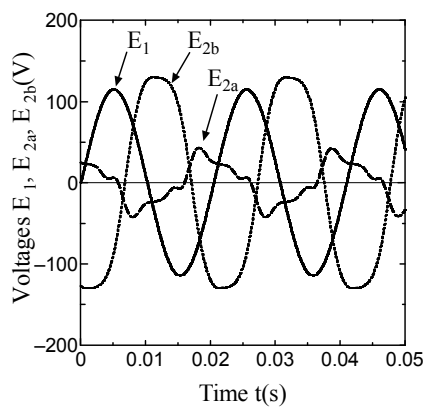

(b) \#1L(-60) ${ }^{\circ}$

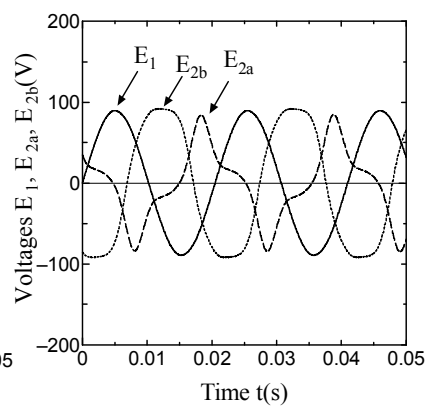

(c) \#2/3L $60^{\circ}$ Cross



(d) \#1/2L $60^{\circ}$ Cross

Fig. 9 Three-phase voltage waveforms of each motor. 
モータの周波数増加後の波形を示す.この周波数の増加後, 励磁電圧を降下していく過程において三相電圧が出力さ れた. また, CW 始動時の場合, \#1L(-60)以外のモータで は, 励磁電圧を増加していく過程において共振側 B の発振 条件が整い, 三相電圧が出力されたが, その後, 再び励磁 電圧を増加すると, コンデンサ容量の小さい側の共振側周 波数が増加した状態に移行する. このとき周波数が増加し た状態が崩れると，\#2/3L60Cross のように励磁電圧を降 下していく過程において三相電圧は出力されなくなる．よ って，これらのことから，このコンデンサ容量の小さい側 の共振側周波数の増加が, 三相電圧確立に関係していると 考えられる。

しかし，\#1L60では, CCW 始動時において励磁電圧を 増加していく過程でコンデンサ容量の小さい側の共振側周 波数が増加したが, その後に三相電圧は出力されなかった. これは, コンデンサ容量の大きい側の発振条件が整ってお らず，また，CW 方向に回転をするという要因を満たして いなかったためだと考えられる.よって，このようにただ 周波数が増加をするということだけでは三相電圧は出力 されない. Fig. 11 に文献[9]で解析された励磁電圧 $\mathrm{E}_{1}$ と同 調用コンデンサ C に対するパラメトリック発振の確立領 域図を示す9). 同図の黒く塗られた領域 I が基本周波を表 しており，続けて，倍周波，3 倍周波の領域ということを 表している. 同図より, コンデンサ容量が小さく電圧が大 きくなった場合, 周波数が基本周波から倍周波，もしくは 3 倍周波に移行しや寸いということが見て取れる。このこ とから，コンデンサ容量の小さい側の共振側電圧が，励磁 電圧と発振条件の整ったコンデンサ容量の大きい側の共 振側電圧の影響を受けて, 周波数が増加したと考えられる。 よって, ただ周波数が増加するのではなく, 上記の条件を 満たした周波数の増加が三相電圧確立の要因といえる.

\section{4. おわりに}

パラメトリック発振電圧確立機構について検討を行っ た結果, 三相電圧が出力されるために必要な要因を明らか にすることができた．以下にこれを述べる．

まず，回転方向に着目すると， $\mathrm{C}_{\mathrm{a}}=10 \mu \mathrm{F}, \mathrm{C}_{\mathrm{b}}=20 \mu \mathrm{F}$ を 使用した場合, CCW 方向に動作をした状態では三相電圧 は出力されることがなかった.しかし, 励磁側波形に対し て共振側 $\mathrm{A}$ の波形が進み位相, 共振側 $\mathrm{B}$ の波形が遅れ位 相となることにより三相類似波形が出力されたことから， CW 方向に回転をすることが望ましいといえる.

また，倍周波発振に関しては，コンデンサ容量の大きい 側の発振条件が整い $\mathrm{CW}$ 方向に回転をし始めた際, コンデ ンサ容量の小さい側の周波数が $100 \mathrm{~Hz}, 150 \mathrm{~Hz}$ に増加を した. その後, 励磁電圧を降下していく過程において三相 電圧が出力された. また, $\mathrm{CW}$ 始動時の場合, 励磁電圧を 増加していく過程において三相電圧が出力されるモータ もあり，それらのモータでは，励磁電圧を増加し続け三相 波形が崩れた際，コンデンサ容量の小さい側の周波数が増 加した状態に移行する。この状態が崩れると, 励磁電圧を 増減させても三相電圧は出力されなかった。 よって, コン デンサ容量の小さい側の倍周波、3 倍周波発振が三相電圧 出力の要因の一つとして明確となった.

しかし，これらの要因はどちらか片方の条件が満たされ ていても三相電圧が出力されなかったことから, 三相電圧 確立のためには, この二つの要因が同時に行われる必要が あるといえる。

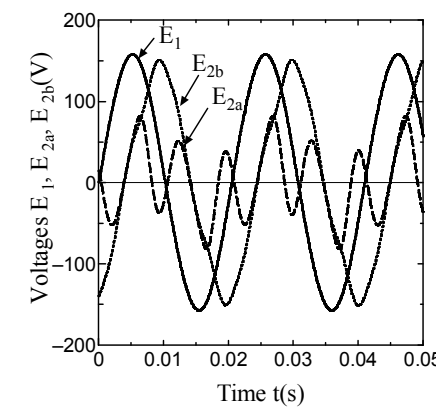

(a) \#1L60



(b) \#1L(-60) ${ }^{\circ}$

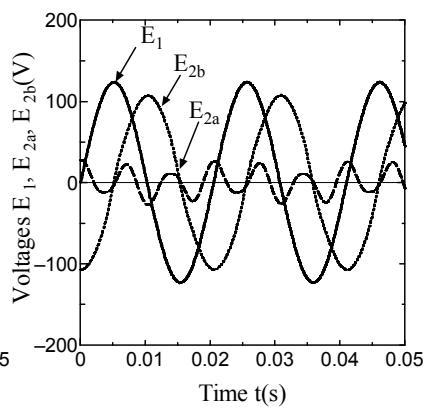

(c) \#2/3L $60^{\circ} \mathrm{Cross}$

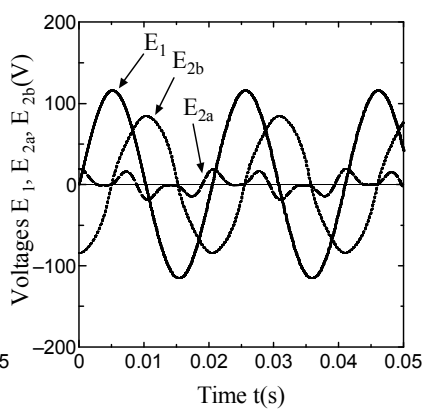

(d) \#1/2L $60^{\circ}$ Cross
Fig. 10 Occursion of multiple frequency oscillation.

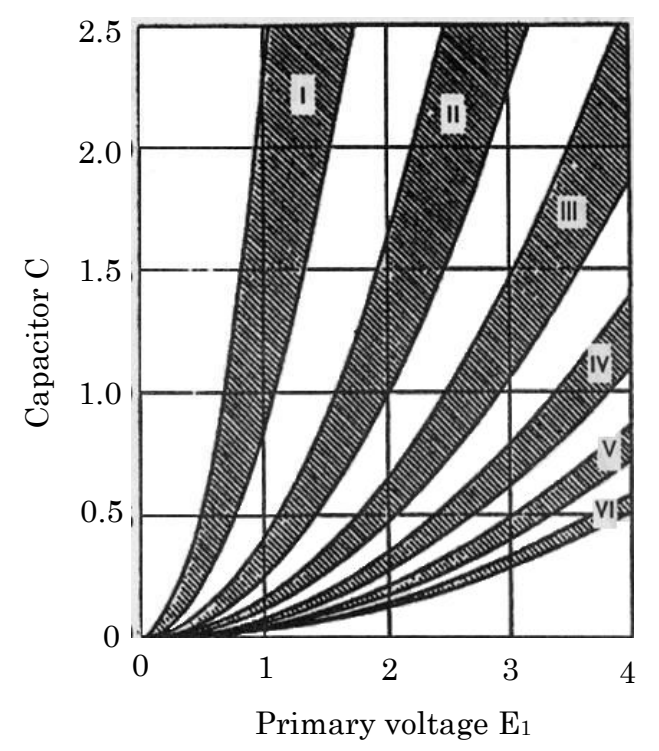

Fig. 11 Nonlinear Oscillations in Physical Systems. 
また，これらの要因は，磁気異方性を設けたことによる 影響，および，共振側磁極の断面積に違いによる影響があ るモータでも三相電圧確立の要因として同じ事が明確と なったことから，この二つの要因は三相パラメトリックモ 一タを研究していく上で重要なものであるといえる.

今後は，今回検討を行った二つの要因が，どちらともコ ンデンサ容量が大きい側の発振条件が整うことにより起 きた現象であることから，その発振条件が整う要因を追及 する必要がある。

\section{References}

1) T. Yashima, M. Ohta, T. Ohkubo, T. Hiwatashi, M.

Natsusaka, and Y. Sakamoto: J. Magn. Soc. Jpn., 26, 673

(2002).

2) T. Yashima, S. Oikawa, M. Natsusaka, Y. Sakamoto:

J.Magn.Soc.Jpn., 27, 526 (2003).

3) T. Yashima, M. Natsusaka, Y. Sakamoto: I.E.E Japan Mag-02-149 (2002).

4) T. Yashima, M. Natsusaka, M. Ohta, Y. Sakamoto: I.E.E, Japan MAG-01-156, LD-01-84 (2001).

5) Y. Satomi, T. Yashima, M. Natsusaka, Y. Sakamoto: J.Magn 146-16PS-27 (2003).

6) T. Ibata, M. Natsusaka, and Y. Sakamoto: J. Magn. Soc. Jpn., 31, 246 (2007).

7) Y. Tosa, M. Ohkubo, M. Natsusaka, and Y. Sakamoto: $J$. Magn. Soc. Jpn, 27, 522 (2003).

8) J. Ishikawa, M. Natsusaka, and Y. Sakamoto: J. Magn, $14 \mathrm{pB}-2(2007)$

9) C.Hayashi, "Nonlinear Oscillations in Physical Systems", McGrow-Hill, 1964.

2009 年 10 月 15 日受理, 2010 年 1 月 6 日再受理, 2010 年 3 月 17 日採録 